\section{DiscoverSys \\ Published by DiscoverSys \\ High parity and chronic energy deficiency increase risk for low birth weight in Situbondo District}

\author{
Dyah Ekowati, ${ }^{1,2^{*}}$ Luh Seri Ani, ${ }^{2,3}$ I Gusti Ayu Trisna Windiani ${ }^{2,4}$
}

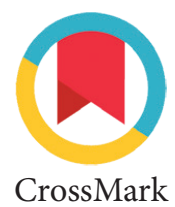

CrossMark

\begin{abstract}
Background and purpose: The prevalence of low birth weight (LBW) in Situbondo District increased from 2.79\% in 2008 to $5.85 \%$ in 2014. The highest prevalence in 2015 was found in Bungatan Subdistrict (11\%). This study aims to determine risk factors of LBW in Bungatan Subdistrict, Situbondo.

Methods: A case control study was conducted in Bungatan Subdistrict. A total of 60 infants born at the Bungatan Public Health Centre were included in the study. Cases were infants with LBW and controls were those with normal birth weight. All infants born with LBW were taken as cases (20 infants) while 40 controls were selected using a systematic random sampling. Data were collected from February to March 2016. Data were analysed using bivariate and multivariate technique with logistic regression test.
\end{abstract}

Results: The majority of respondents were unemployed (80\%), aged between 20-35 years during the pregnancy $(53.33 \%)$, with parity of $\leq 3(66.67 \%)$, low education level $(61.67 \%)$, anemia during the pregnancy (68.33\%), good nutritional status (75.00\%), poor nutrition intake during the pregnancy (51.67\%) and without pre-eclampsia $(88.33 \%)$. Parity of $>3$ increased the risk of LBW (AOR $=6.4 ; 95 \% \mathrm{Cl}$ : 1.66-24.75). Chronic energy deficiency increased the risk of LBW (AOR=5.6; 95\%Cl: 1.41-22.57).

Conclusions: Parity of more than three and chronic energy deficiency increase the risk for LBW in Bungatan Public Health Centre, Situbondo District.
${ }^{1}$ Midwifery Academy of Bina Husada Jember,

${ }^{2}$ Public Health Postgraduate Program Udayana University, ${ }^{3}$ Department of Community and Preventive Medicine Faculty of Medicine Udayana University, ${ }^{4}$ Department of Paediatric Faculty of Medicine Udayana University

*Correspondence to: Dyah Ekowati, Midwifery Academy of Bina Husada Jember

dyahekowati0706@yahoo.com

Keywords: parity, chronic energy deficiency, LBW, case control, Situbondo Cite This Article: Ekowati, D., Ani, L.S., Windiani, I.G.A.T. 2017. High parity and chronic energy deficiency increase risk for low birth weight in Situbondo District. Public Health and Preventive Medicine Archive 5(1):28-32. D01:10.15562/phpma.v5i1.38

\section{INTRODUCTION}

Low birth weight (LBW) is a global public health issue. LBW is one of major causes for infant mortality. About $60 \%-80 \%$ of infant mortality cases were caused by LBW. Annually, 20 million or $15.5 \%$ of the global live births were LBW for which $96.5 \%$ were found in developing countries. The prevalence of LBW was $16.5 \%$ in developing countries while in developed countries was only 7\%. ${ }^{1}$ Data from Basic Health Survey (Riskesdas) 2013 showed that the prevalence of LBW was $10.2 \%$ from all births. The prevalence of LBW in East Java was $11.2 \%$ of all births. ${ }^{2}$ Situbondo District, one district at East Java also experienced an increased prevalence of LBW from $2.79 \%$ in 2008 to $5.85 \%$ in 2014 . The highest LBW prevalence in 2015 was found in Bungatan Subdistrict $(11 \%)$. $^{3}$

Studies examining risk factors of LBW have been conducted in many areas and countries. Findings from these studies are still inconsistent and the majority were conducted at the hospital and not many studies adopted community based research., ${ }^{4,5,6,7}$ The high prevalence of LBW in Bungatan Subdistrict indicates the need for a further study examining its associated risk factors. Understanding these risk factors will enable further preventative measures. This present study aims to understand risk factors associated to LBW in Bungatan Subdistrict, Situbondo.

\section{METHODS}

A case control study was conducted at Bungatan Public Health Centre from February to March 2016. Case population was all new born babies with LBW and control population was all babies with normal birth weight at Bungatan District in 2015. All babies with LBW were recruited as samples (20 cases) and 40 controls were selected using a systematic random sampling. Data were collected by visiting respondents' house. Data were obtained from ANC book that included age of mother during pregnancy, parity, education level, employment status, anemia status, nutritional status, body weight prior to delivery, upper arm diameter, pre-eclampsia, gestation age, birth weight, baby conditions after the delivery such as single or twin and congenital disease. Informed consent was obtained prior to the data collection.

Data were analysed using univariate, bivariate and multivariate technique in Stata 12.1. Univariate analysis was conducted to describe characteristics of respondents and other variables. Bivariate analysis was done by creating cross-tabulation and chi square test was performed. Variables with p-value $<0.25$ on bivariate analysis and theoritically have an 
association with LBW were included in the multivariate analysis using logistic regression model to calculate the adjusted odd ratio (AOR) with 95\% confidence interval. This present study has been approved by Human Research Ethics Committee of Malang Health Polytechnic.

\section{RESULTS}

Table 1 shows that the majority of respondents were mothers with parity $\leq 3$, unemployed during pregnancy, aged between 20-35 years, with low education level, anemic, without chronic energy deficiency (CED), without pre-eclampsia and with inadequate body weight gain during pregnancy. Table 2 shows the comparison between cases and control regarding parity, employment status, age of mother, education level, anemia status, CED status, improved weight gain and pre-eclampsia status. It reveals that only parity and CED status were significantly different between cases and controls.

Table 3 shows that CED status increased risk for LBW $(\mathrm{OR}=4.6 ; 95 \% \mathrm{CI}: 1.34-15.96)$. In order to obtain

\section{Table 1 Respondent characteristics}

\begin{tabular}{|c|c|c|}
\hline Variables & $n=60$ & $\%$ \\
\hline \multicolumn{3}{|l|}{ Parity } \\
\hline$>3$ & 20 & 33.33 \\
\hline$\leq 3$ & 40 & 66.67 \\
\hline \multicolumn{3}{|l|}{ Employment status } \\
\hline Employed & 12 & 20.00 \\
\hline Unemployed & 48 & 80.00 \\
\hline \multicolumn{3}{|c|}{ Age during pregnancy } \\
\hline$<20$ or $>35$ years & 28 & 46.67 \\
\hline 20-35 years & 32 & 53.33 \\
\hline \multicolumn{3}{|l|}{ Education level } \\
\hline Low & 37 & 61.67 \\
\hline High & 23 & 38.33 \\
\hline \multicolumn{3}{|l|}{ Anemia status } \\
\hline Yes & 41 & 68.33 \\
\hline No & 19 & 31.67 \\
\hline \multicolumn{3}{|l|}{ CED status } \\
\hline Yes & 15 & 25.00 \\
\hline No & 45 & 75.00 \\
\hline \multicolumn{3}{|c|}{ Body weight improvement } \\
\hline Poor & 31 & 51.67 \\
\hline Adequate & 29 & 48.33 \\
\hline \multicolumn{3}{|l|}{ Pre-eclampsia status } \\
\hline Yes & 7 & 11.67 \\
\hline No & 53 & 88.33 \\
\hline
\end{tabular}

the adjusted odd ratio, all variables with $\mathrm{p}$ value of $<0.25$ from bivariate analysis were included in the logistic regression model that were parity, employment status, age during pregnancy, anemia status, CED status and weight gain status. Table 4 shows that parity of $>3$ and CED status were risk factors for LBW. Parity $>3$ increased risk for LBW (AOR=6.4; 95\%CI: 1.66-24.74). CED status increased risk for LBW (AOR=5.6; 95\%CI: 1.41-22.57).

\section{DISCUSSION}

This study showed that parity of $>3$ increases the risk of LBW (AOR=6.4; 95\%CI: 1.66-24.74; $\mathrm{p}=0.007)$. This finding is consistent with several studies in Gorontalo, Malaysia, Poland and Congo. ${ }^{8,9,10,11}$ Higher parity $(>3)$ is associated with LBW and perinatal mortality. ${ }^{12}$ Repeated pregnancies lead to alteration of blood vessels in the uterus. This disturbs the nutrient flow from mother to the baby that leads to interruption of fetal growth and results in LBW infant. ${ }^{13}$ Family planning is a government's program to control population growth through limiting the number of pregnancies. However, community participation in family planning program at Bungatan Public Health Centre is lacking, with the coverage is only $50 \% .{ }^{14}$ Level of knowledge regarding contraception methods and its availability at the health centre are essential for community participation in the family planning program. ${ }^{15}$ Providing information, education and communication on contraception methods may improve the uptake of family planning program. ${ }^{16}$ It is expected that Bungatan Public Health Centre is more proactive in providing information and education on family planning. These activities should target not only married couple but also reproductive aged women more generally.

Multivariate analysis showed that CED status increases the risk of $\mathrm{LBW} \quad(\mathrm{AOR}=5.6$; 95\%CI: 1.41-22.57; $\mathrm{p}=0.014$ ). Pregnant women with CED are 5.6 times more likely giving birth to LBW infant. This finding is consistent with other studies in Singkawang, Sumenep and Bantul. ${ }^{5,17,18}$ CED during pregnancy is caused by the lack of nutrient intake. CED during pregnancy may reduce the blood volume thus decreases the cardiac output and blood volume to the placenta. The lack of blood being pumped into the placenta reduces the nutrient flow from mother to the baby and may lead to fetal growth inhibition. ${ }^{19}$

The measurement of upper arms diameter is one method which can be used to detect CED among pregnant women. ${ }^{20}$ However, the coverage of nutrition program in Bungatan Public Health Centre is still $81.13 \%$. In addition, the coverage of nutrition program for pregnant women is only 
Table 2 Comparison between cases and controls based on several variables

\begin{tabular}{|c|c|c|c|}
\hline Variables & $\begin{array}{l}\text { LBW } \\
\text { n (\%) }\end{array}$ & $\begin{array}{c}\text { Normal weight } \\
\text { n (\%) }\end{array}$ & p value \\
\hline \multicolumn{4}{|l|}{ Parity } \\
\hline$>3$ & $11(55.00)$ & $9(22.50)$ & 0.012 \\
\hline$\leq 3$ & $9(45.00)$ & $31(77.50)$ & \\
\hline \multicolumn{4}{|l|}{ Employment status } \\
\hline Employed & $6(30.00)$ & $6(15.00)$ & 0.171 \\
\hline Unemployed & $14(70.00)$ & $34(85.00)$ & \\
\hline \multicolumn{4}{|c|}{ Age of mothers during pregnancy } \\
\hline$<20$ or $>35$ years & $12(60.00)$ & $16(40.00)$ & 0.143 \\
\hline 20-35 years & $8(40,00)$ & $24(60.00)$ & \\
\hline \multicolumn{4}{|l|}{ Education level } \\
\hline Low & $14(70.00)$ & $23(57.50)$ & 0.348 \\
\hline High & $6(30.00)$ & $17(42.50)$ & \\
\hline \multicolumn{4}{|l|}{ Anemia status } \\
\hline Yes & $16(80.00)$ & $25(62.50)$ & 0.170 \\
\hline No & $4(20.00)$ & $15(37.50)$ & \\
\hline \multicolumn{4}{|l|}{ CED status } \\
\hline Yes & $9(45.00)$ & $6(15.00)$ & 0.011 \\
\hline No & $11(55.00)$ & $34(85.00)$ & \\
\hline \multicolumn{4}{|l|}{ Weight gain status } \\
\hline Inadequate & $13(65.00)$ & $18(45.00)$ & 0.144 \\
\hline Adequate & $7(35.00)$ & $22(55.00)$ & \\
\hline \multicolumn{4}{|l|}{ Pre-eclampsia status } \\
\hline Yes & $3(15.00)$ & $4(10.00)$ & 0.570 \\
\hline No & $17(85.00)$ & $36(90.00)$ & \\
\hline Total & $20(100.00)$ & $40(100.00)$ & \\
\hline
\end{tabular}

${ }^{*}$ Chi Square test

Table 3 Crude odd ratio for LBW

\begin{tabular}{|c|c|c|c|c|c|}
\hline Variables & $\begin{array}{l}\text { LBW } \\
\text { n (\%) }\end{array}$ & $\begin{array}{c}\text { Normal weight } \\
\text { n (\%) }\end{array}$ & Crude OR & $95 \% \mathrm{Cl}$ & p value \\
\hline \multicolumn{6}{|c|}{ Mother's age during pregnancy } \\
\hline$<20$ or $>35$ years & $12(60.00)$ & $16(40.00)$ & 2.2 & $0.75-6.73$ & 0.147 \\
\hline $20-35$ years & $8(40.00)$ & $24(60.00)$ & & & \\
\hline \multicolumn{6}{|l|}{ Education level } \\
\hline Low & $14(70.00)$ & $23(57.50)$ & 1.7 & $0.54-5.41$ & 0.350 \\
\hline High & $6(30.00)$ & $17(42.50)$ & & & \\
\hline \multicolumn{6}{|l|}{ Anemia status } \\
\hline Yes & $16(80.00)$ & $25(62.50)$ & 2.4 & $0.67-8.53$ & 0.176 \\
\hline No & $4(20.00)$ & $15(37.50)$ & & & \\
\hline \multicolumn{6}{|l|}{ CED status } \\
\hline Yes & $9(45.00)$ & $6(15.00)$ & 4.6 & $1.34-15.96$ & 0.015 \\
\hline No & $11(55.00)$ & $34(85.00)$ & & & \\
\hline \multicolumn{6}{|l|}{ Weight gain status } \\
\hline Inadequate & $13(65.00)$ & $18(45.00)$ & 2.2 & $0.74-6.88$ & 0.148 \\
\hline Adequate & $7(35.00)$ & $22(55.00)$ & & & \\
\hline \multicolumn{6}{|l|}{ Pre-eclampsia status } \\
\hline Yes & $3(15.00)$ & $4(10.00)$ & 1.5 & $0.31-7.89$ & 0.572 \\
\hline No & $17(85.00)$ & $36(90.00)$ & & & \\
\hline
\end{tabular}




\begin{tabular}{|c|c|c|c|c|c|c|}
\hline \multirow[b]{2}{*}{ Variable } & \multicolumn{3}{|c|}{ Initial model } & \multicolumn{3}{|c|}{ Final model } \\
\hline & Adjusted OR & $95 \% \mathrm{Cl}$ & p value & Adjusted OR & $95 \% \mathrm{Cl}$ & p value \\
\hline Age of mother $<20$ or $>35$ years & 1.6 & $0.40-6.48$ & 0.502 & - & - & - \\
\hline Anemia & 2.1 & $0.50-9.54$ & 0.294 & - & - & - \\
\hline CED & 5.3 & $1.26-22.85$ & 0.022 & 5.6 & $1.41-22.57$ & 0.014 \\
\hline Inadequate weight gain & 3.2 & $0.82-12.82$ & 0.092 & 3.0 & $0.80-11.21$ & 0.101 \\
\hline Employed & 0.7 & $0.14-3.58$ & 0.696 & - & - & - \\
\hline Parity $>3$ & 5.7 & $1.27-25.53$ & 0.023 & 6.4 & $1.66-24.74$ & 0.007 \\
\hline
\end{tabular}

$54 \% .{ }^{14}$ The nutrition improvement program targeting pregnant women is implemented by the health centre by providing milk and nutrition counselling. However, the milk supplementation is not routinely conducted by the district health office. Nutritional improvement program for pregnant women with CED is done based on local contexts which include epidemiological, socio-cultural and local capacity. This program consists of education on consumption pattern, food supplementation equal to $\pm 500 \mathrm{kcal}$ and $15 \mathrm{gr}$ of protein daily, and monitoring of fetal development. If the weight gain of $1 \mathrm{~kg} / \mathrm{month}$ during first trimester or $2 \mathrm{kgs} / \mathrm{month}$ during second trimester are not achieved, they should be referred to the health centre and the nutritionist.

Addressing CED in pregnant women requires collaboration between programs and cross-sectoral partnership including family, health cadre, village midwives, public health centres, nutritionist, head of public health centre, nutritional team at the health centre and health offices. ${ }^{21}$ It is suggested that health offices should support the provision of nutrition program targeting pregnant women with CED by encouraging participation from cross programs and sectors.

This study has several limitations. Firstly, this study only covers Bungatan Subdistrict Situbondo Regency therefore it might not be applicable to other areas across Indonesia. Secondly, cases and controls in this study were taken from the delivery register at the public health centre which may not sufficiently represent the whole population.

\section{CONCLUSION}

Parity of $>3$ and CED status are risk factors for LBW in Bungatan Public Health Centre, Situbondo District.

\section{ACKNOWLEDGEMENT}

We would like to thank the Health Office of Situbondo District, the head of Bungatan Public
Health Centre, midwives and all respondents who have participated in this study.

\section{REFERENCES}

1. UNICEF \& WHO. Low Birth Weight, Country, Regional and Global Estimates. New York: United Nations Children's Fund and World Health Organization; 2004

2. Ministry of Health of Indonesia. Riset Kesehatan Dasar (Riskesdas) [Basic Health Survey]. Jakarta: Kementrian Kesehatan RI; 2013.

3. Situbondo District Health Office. Profil Kesehatan Kabupaten Situbondo Tahun 2014 [Health Profile of Situbondo District 2014]. Kabupaten Situbondo; 2015.

4. Lestaringingsih S, Duarsa ABS. Hubungan preeklamsia dalam kehamilan dengan kejadian BBLR di RSUD Jenderal Ahmad Yani Kota Metro Tahun 2011 [Association between pre-eclampsia and the low birth weight incidence at Jenderal Ahmad Yani Kota Metro District Hospital]. Jurnal Kesehatan Masyarakat; 2013; 8 (1).

5. Trihardiani I. "Faktor risiko kejadian BBLR di Wilayah Puskesmas Singkawang Timur dan Utara Kota Singkawang [Risk factors of low birth weight in East Singkawang and North Singkawang City]" (thesis). Semarang: Universitas Diponegoro; 2011.

6. Xaverius P, Alman C, Holtz L, Yarber L. Risk factors associated with very low birth weight in a large urban area, stratified by adequacy of prenatal care; 2016. Retrieved from https://www.ncbi.nlm.nih.gov/pubmed/26537389

7. Oladeinde HB, Oladeinde OB, Omoregie R, Onifade AA. Prevalence and determinants of low birth weight: the situation in a traditional birth home in Benin City, Nigeria; 2015. Retrieved from https://www.ncbi.nlm.nih.gov/ pubmed/2 6958012

8. Amalia L. Faktor risiko kejadian bayi berat lahir rendah (BBLR) di RSU Dr. MM Dunda Limboto Kabupaten Gorontalo [Risk factors of low birth weight in General Hospital of Dr. MM Dunda Limboto, Gorontalo District]. Jurnal Sainstek; 2011; 6(3).

9. Yodav H, Lee N. Maternal factors in predicting low birth weight babies; 2013. Retrieved from http://www.ncbi.nlm. nih.gov/pubmed/23466766

10. Merklinger-Gruchala A, Jasienska G, Kapiszewska M. Short interpregnancy interval and low birth weight: a role of parity; 2015. Retrieved from http://www.ncbi.nlm.nih. gov/pubmed/25754897

11. Mabiala-Babela JR, Matingou UC, Sergo P. Risk factors for low birth weight in Brazzaville, Congo; 2007. Retrieved from http://www.ncbi.nlm.nih. gov/pubmed/17630227

12. Wiknjosastro, H. Ilmu Kebidanan [Midwifery Science]. Jakarta: Yayasan Bina Pustaka Sarwono Prawirohardjo; 2012.

13. Manuaba. Buku Ajar Patologi Obstetri untuk Mahasiswa Kebidanan [Text Book on Pathological Obstetric for Medical Students]. Jakarta: Penerbit Buku Kedokteran EGC; 2008. 
14. Bungatan Public Health Centre. Laporan Penilaian Kinerja Puskesmas Bungatan Tahun 2015 [Performance Assessment Report of Bungatan Public Health Centre]. Kabupaten Situbondo: Puskesmas Bungatan; 2015.

15. Afni N. Hubungan pengetahuan akseptor $\mathrm{KB}$ dengan penggunaan alat kontrasepsi di Puskesmas Helvetia Medan [Association between level of knowledge of family planning acceptors and the usage of contraceptive methods in Helvetia Public Health Centre, Medan].; 2008. Retrieved from http://Uda.ac.id/journal/journal\%20bu\%Selly\%20 vol\%202

16. Musdalifah M. "Faktor yang berhubungan dengan pemilihan kontrasepsi hormonal pasutri di Wilayah Kerja Puskesmas Lampa Kecamatan Duampanua Kabupaten Pinrang" [Factors associated to the use of hormone contraceptives among married couple at Lampa Public Health Centre, Duampanua Subdistrict, Pinrang District] (skripsi). Fakultas Kesehatan Masyarakat Universitas Hasanudin; 2013.

17. Festy P. "Analisis faktor risiko pada kejadian berat badan lahir rendah di Kabupaten Sumenep [Analysis of risk factors among low birth weight cases in Sumenep District]" (skripsi). Surabaya: Universitas Muhammadiyah Surabaya; 2010.

18. Syarifuddin. "Kurang energi kronik (KEK) ibu hamil sebagai faktor risiko bayi berat lahir rendah (BBLR) di Kabupaten Bantul [Chronic energy deficiency as a risk factor for low birth weight in Bantul District]" (thesis). Yogyakarta: Universitas Gajah Mada; 2011.
19. Albugis, D. "Faktor-faktor yang mempengaruhi kekurangan energi kronik (KEK) pada ibu hamil di wilayah Puskesmas Jembatan Serong Kecamatan Pancoran Mas Depok Jawa Barat [Factors associated to chronic energy deficiency among pregnant women in Jembatan Serong Community Health Centre, Pancoran Mas Subdistrict, Depok-West Java]" (skripsi). Depok: Universitas Indonesia; 2008.

20. Supariasa, IDN, Bakri, B, Fajar, I. Penilaian Status Gizi [Nutritional Status Assessment]. Jakarta: Penerbit Buku Kedokteran EGC; 2002.

21. Direktorat Bina Gizi Kemenkes RI. Pedoman Penanggulangan Kurang Energi Kronik (KEK) pada Ibu Hamil [Guideline on Management of Chronic Energy Deficiency among Pregnant Women]. Jakarta: Kementrian Kesehatan RI; 2015.

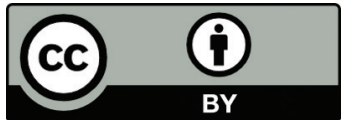

This work is licensed under a Creative Commons Attribution 